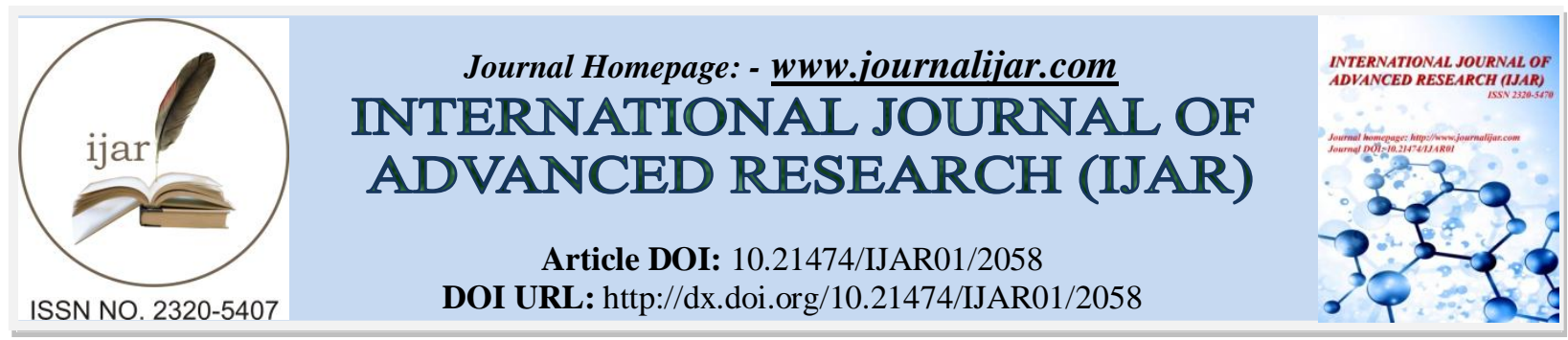

RESEARCH ARTICLE

\title{
STUDENTS' NON-SCHOOL ATTENDANCE AMONG SECONDARY SCHOOL STUDENTS IN IBADAN: IMPLICATION FOR COUNSELLING
}

OJO Funmilayo Yemi ${ }^{1}$, OJO Philip $\mathrm{O}^{2}$ and ONAOLAPO Abayomi Philip ${ }^{3}$.

1. Head, Counselling Unit Afe Babalola University Ado-Ekiti, Ekiti State, Nigeria.

2. National Open University of Nigeria Ibadan Study Centre.

3. School of Arts and social sciences, National Open University of Nigeria Ibadan Study Centre.

\section{Manuscript Info}

\section{Manuscript History}

Received: 23 September 2016

Final Accepted: 25 October 2016

Published: November 2016

Key words:-

Student, non-school attendance,

Counselling.

\section{Abstract}

School attendance is of necessity and very important for academic success and moral development of learners. There is no doubt that issue of school attendance in Nigeria among secondary school students has contributed largely to the poor performance of students in examination conducted internally and externally, hence the need for this study.

The study adopted a descriptive survey research design using ex-post facto type. Purposive sampling technique was used to select two hundred (200) participants for the study. Three hypotheses were generated and tested for the study at 0.05 alpha levels. The main instrument for the study was Student Attendance Behaviour Scale (SABS; $r=0.83$ ) was used to generate data for the study. Data were analyzed using Student t test statistic.

There were significant differences in the level of truancy behaviour between: male and female participants $\left(\mathrm{t}_{\mathrm{obs}}=11.08 ; \mathrm{df}=198 ; \mathrm{p}>\right.$ $0.05)$; participants from monogamous and polygamous families $\left(\mathrm{t}_{\mathrm{obs}}=\right.$ 274.15; df =198; $>$ > 0.05). The result also indicated that there was a significant difference in the truancy behaviour between participants from literate and non-literate homes $(\mathrm{t}=24.25 ; \mathrm{df}=198 ; \mathrm{p}<0.05)$.

The study concluded that truancy is a bad habit. It was therefore recommended that school administrators, counselors, teachers and parents should endeavour to identify factors leading to truancy among learners with a view to develop appropriate intervention.

Copy Right, IJAR, 2016,. All rights reserved.

\section{Introduction:-}

School attendance behaviour is a serious issue and essential pre-requisite for achievement and overall development of learners (Animasahun, 2008). Chronic absenteeism is a behaviour that is highly associated with dropping out of school. In fact, non-school attendance (also referred to as truancy) by learners most especially among adolescents, has become common occurrence in educational settings. Truancy among students has been defined as the act of absenting oneself from school without a legitimate reason and without the permission of the parents or the school authorities (Herbert, 2005). It has attracted interest in public discussion as well as in educational research. Since school attendance is of necessity and very important for academic success and moral development of learners. Truancy can mar the potential educational attainment of learners as well as other benefits of educational setting. 
There is no doubt that the issue of student's truancy in Nigeria's school system has attained an alarming proportion. It has been a great concern to the parents, school authorities, teachers, educational practitioners and the government.

Nwana (2004) explained that truancy is an intentionally absenting oneself from school without permission, leaving without authorization and dodging specific lessons period. It is further stressed that truancy and absenteeism in school are deleterious of adolescent rebellion, self-assertion and reaction over certain developmental and psychological problems. Truancy is usually not a single issue with youth but a symptom of more serious problems such as all forms of family disorganization, urbanization, poverty, peer relationships or engaging in delinquent behaviour (Farrington, 2002). Thus, youth are to be informed of the evils that can befall them when they allow themselves to be influenced by these environmental factors.

Ubogu (2004) identified causes of truancy as illness, financial hardship, age, social class, geographical area and institutional influence. School related factors such as teachers' attitude, poor administration, and high cost of education. Others are distance to school; family background, school discipline, and school location are among causes of truancy among students (Emore, 2005). Siziya, Muula and Rudatsikira (2007) in their study found that truancy among adolescents had been reported to engage in risky sexual practice, illicit drug use, alcohol drinking and cigarette smoking. Carrol (1996) found that truancy and poor attendance at school are most likely to be found among large families where the father is a manual worker. Maynard (2014) posits that parents of poor school attendees were perceived by their children as being at a loss when it came to demonstrating interest in their children's education. Parents' inability to model and promote discipline and dedication at the micro level of bioecological theoretical framework, place their children at an academic disadvantage compared to those children who enjoyed the support and interest of their parents. This would invariably have an adverse effect on their children's attitude towards school attendance and on how they value the significance of education. Studies uniformly report higher truancy rates for males than females, but females are twice as likely as males to be absent with parental consent. Female truants are said to demonstrate lower anti-social behavior than truant males, while truant males tend to perceive the school experience more negatively than truant females, a factor thought to contribute to the higher rates of male truancy observed in virtually every extant study available include (Caldas, 1993; Eastwood, 1989; Ensminger \& Slusarcick, 1992; Farrington, 1980; Galloway, 1982).

Truancy has been linked empirically in some studies to specific types of serious juvenile delinquency activity such as substance abuse, gang involvement, burglary, auto-theft, and vandalism (Baker et al., Henry, 2007). Jesse (2014) reported that truancy is a gateway tocrime in that a great majority of inmate in adult jails report that their first appearance before a judge was as a juvenile on truancy charges. Children who perform poorly at school are more likely to be a truant which is also a link to delinquency (Walklate, 2003). Also, Maynard (2006) observes that the implications of non school attendance become more worrying when concern is drawn to instances of truancy leading to delinquency, social disorder and educational failure.

Counselling is a helping relationship that can be entered into by a professional counsellor with one person only (individual counselling) or with two or more persons (group counselling). Nwoje (2001) viewed counselling as the integral part of guidance which provides the forum for interaction and exchange of views between the client and the counsellor. According to Uzoeshi (2004), counselling is aimed at assisting the client to overcome his problems and become happier and more effective. Good guidance counselling helps young people to accept challenges and live stress free life by becoming resilient. In tandem Akinade, (1996) opines that the scientific and professional resources to make help available to the troubled youth is the school counsellor. Since behavior is caused, there is the opportunity to alter the behaviour of youth, by helping them restructure their cognitive belief and by creating new social arrangement, this requires the services of professional counsellors.

The magnitude of prevalence of truancy remains a factor yet to be thoroughly examined among secondary school students. The level of concern over truancy has inevitably resulted in significant effort by researchers, practitioners, schools and policy makers to understand and address this increasingly serious problem (Maynard, 2014). However, much of the extant literature focuses predominantly on the school and community related factors which lead to truant behaviour, with limited attention being paid to the contribution of school guidance counsellors. The study therefore looks at the impact of school counselling services to curb students' non-school attendance among secondary school students in Ibadan, Nigeria. 


\section{Purpose of study:-}

The purposes of this study therefore, was to look at the impact of school guidance counselling as remedy for nonschool attendance among secondary school students in Ibadan, Nigeria

\section{Research Hypotheses:-}

The following null hypotheses were stated and tested for, in this study at alpha level of 0.05 .

- There is no significant difference in the level of truancy between the male and female participants.

- There is no significant difference in the level of truancy between participants from educated and non-educated families.

\section{Research design:-}

The research design adopted for this study was a descriptive survey research design using an ex-post facto type. This design was adopted because the study only attempts to study the situation as it is, thus there is no intervention on the part of the researcher and therefore no control. The researcher only attempt to determine the cause, or reason for preexisting differences in group of individuals. Ex-post facto (Latin for 'after the fact') was employed, since both the cause and the alleged effect had occurred and must be studied in retrospect.

\section{Participants:-}

The total number of participants for the study was two hundred (200). The sample consisted of 111 males and 89 females. The participants' age range was between 17 and 19 years, with the mean age of 18.3 years while the standard deviation was 1.73 years.

\section{Instrumentation:-}

The main instrument used for this study is a questionnaire tagged Student's Attendance Behaviour Scale (SABS). The scale consists of two (2) sections, (Sections A \& B). Section A consists of demographical information about the participants while section B consists of twenty (20) items drawn on a 4 point Likert scale type, ranging from SA (4) to Strongly Disagree (1). The respondents are expected to choose and tick from 4, 3, 2 and 1, as it is most applicable to them. The rating corresponds to 1 (Strongly Disagree), 2 (Disagree), 3 (Agree) and 4 (Strongly Agree), so that a higher final score indicates higher level of truancy while a lower score indicates lower level of truancy. The highest score of the scale is eighty (80), while the lowest score is twenty (20).

\section{Validity of the instrument:-}

The instrument was given to two (2) test and measurement experts to determine the face and content validity of the instrument. The instrument was later corrected in line with the corrections made by the experts. The instrument was a non-compound instrument; this is because it was developed on one variable, which is truant behavior.

\section{Reliability of the instrument:-}

The reliability of the instrument was ensured using the tes-retest method for a measure of its consistency and reliability. A sample of thirty (30) students was used for pilot testing of the instrument in a local government area in Ibadan, which was not part of the study area. The researcher administered copies of the instrument to this sample with the request that sample should respond to all the items of the instrument as diligent and honestly as possible. After an interval of two weeks, the same instrument was administered to the same sample to respond as usual. Their reactions to the instrument indicated that the items of the instrument were clearly understood by the respondents. There was no case of item ambiguity. Time allocation of thirty (30) minutes for responding to the entire scale was found to be adequate. Thus, the initial score as well as the retest score of the sample were correlated using Pearson Product Moment Correlation (r). The correlation Coefficient was found to be 0.83. In behavioural research, an alpha of 0.6 or above is acceptable. It is an indication of the reliability of the scale being used (Kerlinger \& Lee, 2000; Ogunyemi, 2001).

\section{Procedure for data collection:-}

Permissions were sought and obtained from the principals of the sampled schools after which the researcher with the cooperation of the class teachers in the sampled schools identified the participants through the record of attendance (register) in their various schools. 
The researcher thereafter administered the instruments on the participants in their respective schools. The researcher with the cooperation of the teachers in the sampled schools participated in the distribution, administration and collection of the research instruments.

Before test, tension reducing statements such as "this is not a test, so there is no right or wrong answer". They were made to understand that they should feel free to give their honest responses as the information supplied will be used for research purpose and treated as confidential. More also the test is not related to their school grades. During the test the researcher attended to few question(s) from the participants as the instructions on the instruments were simple and self-explanatory.

After the test, the researcher with teachers participated in the collection of the instruments. The researcher thanks the participants and discussed with them on the reasons why they should be regular and punctual both in schools and in classes for their various lessons.

\section{Method of Data Analysis:-}

The data that were generated for this study were subjected to t-test statistic to confirm the acceptance or rejection of the null hypotheses.

\section{Results:-}

There is no significant difference in the level of truancy of male and female participants. To test this hypothesis, student's t-test statistic was employed to analyze the data generated for this hypothesis. The result is presented in

Table 1:

Table 1:- t-test Summary table Showing Differences between the level of Truancy Behaviour of male and female participants.

\begin{tabular}{|l|l|l|l|l|l|l|l|l|}
\hline $\begin{array}{l}\text { Variable } \\
\text { Gender }\end{array}$ & $\mathrm{N}$ & $\mathrm{X}$ & $\mathrm{SD}$ & $\mathrm{DF}$ & $\mathrm{t}_{\text {observed }}$ & $\mathrm{t}_{\text {critical }}$ & $\mathrm{P}$ & Remarks \\
\hline Male & 111 & 65 & 3.7 & & & & & \\
\hline & & & 198 & 11.08 & 1.96 & $>0.05$ & $*$ \\
\hline Female & 89 & 59 & 2.9 & & & & & \\
\hline
\end{tabular}

The result presented in Table 1 indicated that there was a significant difference in the truancy level between male and female participants $\left(\mathrm{t}_{\mathrm{observed}}=11.08 ; \mathrm{df}=198 ; \mathrm{p}>.05\right)$. The hypothesis was therefore rejected. The participants did vary significantly from each other in their level of truancy behaviour. The hypothesis was therefore rejected.

\section{Hypothesis two:-}

There is no significant difference in the level of truancy between participants from educated and non-educated homes. To test this hypothesis, student's t-test statistic was employed. The result is as displayed in Table 2:

Table 2:- Comparison of Truancy Behaviour of participants from monogamous and polygamous homes.

\begin{tabular}{|l|l|l|l|l|l|l|l|l|}
\hline $\begin{array}{l}\text { Variable } \\
\text { Family Type }\end{array}$ & $\mathrm{N}$ & $\mathrm{X}$ & $\mathrm{SD}$ & $\mathrm{DF}$ & $\mathrm{t}_{\text {observed }}$ & $\mathrm{t}_{\text {critical }}$ & $\mathrm{P}$ & Remarks \\
\hline Educated & 68 & 64 & 1.9 & & & & & \\
\hline & & & & 198 & 274.15 & 1.96 & $>.05$ & $*$ \\
\hline Non-educated & 132 & 71 & 2.3 & & & & & \\
\hline
\end{tabular}

- $\quad$ Significant at .05 level of significance.

The result as presented in Table 2 indicates that there was a significant difference in the level of truancy between the participants from educated and non-educated homes $\left(\mathrm{t}_{\mathrm{observed}}=274.15 ; \mathrm{df}=198 ; \mathrm{p}>.05\right)$. The hypothesis was hereby rejected. It was therefore concluded that there was significant difference in the level of truancy between the participants from educated and non-educated families. 
One would expect a significant difference to exist in the level of truancy behaviour between participants from educated and non-educated families, but contrary was the case. It was observed from the study that there was no significant difference in the level of truancy between the participants from educated and non-educated homes.

The study also revealed that the level of parental education has no effect on the level of truancy behaviour among secondary school students as there was no significant difference in the level of truancy behavior of participants from educated and non-educated homes. The result of this finding is not surprising because of the popular saying that birds of the same feather flock together. In addition, since students of different families relate together, they are bound to influence each other's behavior because of peer group influence.

\section{Discussion:-}

\section{Hypothesis One:-}

The hypothesis states that there is no significant difference in the level of truancy between male and female participants in the study. The result of the findings from the study revealed that there was no significant difference in the level of truancy between the male and the female participants. The result of this finding is not surprising because gender is not a determining factor in an individual's ability to display any form of behavior.

The result contradicts corroborates that of Fareo (2013) who found significant difference between male and female manifestation of truancy behaviour. Also, Wagner, Dunkalee and Weiss (2004) observed that boys skip classes more than girls in their study. According to Emore (2005), lateness was common among female students than male students. This was as a result of their involvement in domestic activities by their parents.

\section{Hypothesis Two:-}

The study also revealed that the level of parental education has no effect on the level of truancy behaviour among secondary school students as there was no significant difference in the level of truancy behavior of participants from educated and non-educated homes. The result of this finding is not surprising because of the popular saying that birds of the same feather flock together. In addition, since students of different families relate together, they are bound to influence each other's behavior because of peer group influence.

Maynard (2013) findings shows that participants who featured as classic truants perceived their home circumstances as highly unfavourable and disruptive to their school attendance. These truants view their parents' as demonstrating no real regard for their scholastic progress. On the other hand, parents with greater educational aspirations are more likely to engage in communication that revolves around learning and participation in school activities that help their children succeed academically.

\section{Conclusion:-}

It is the belief of the researchers that guidance and counselling can proffer a lasting solution to this serious educational problem. Most students may have abilities and opportunities to study and achieve their ambitions in life but they may not put these abilities and opportunities into use due to peer group influence and may eventually become truants. Therefore, when there is counselling services in school students will be encouraged to accept the responsibility for full utilization of their potentials and opportunities.

In the secondary schools, truants can be labeled as poverty prone and at risk students who are faced with a number of educational challenges which require the building of counsellors' professional capacity to prevent its negative consequences to students and learning. Usually students with high rates of absenteeism, poor academic performance, adjustment problems, lack of interest in schools and poor attitude to school work and learning need the assistance of professional counsellors so as to be able to cope with the academic and social problems and challenges associated with schooling. The persistence and growing phenomenon of truancy among secondary school students suggest the need to build the professional capacity of school counsellors so as to mitigate the negative effects of truancy among secondary school students.

\section{Implications for counseling:-}

Since truancy affects both male and female students, government should therefore deploy qualified counsellors to secondary schools with sufficient funds to establish and equip counselling units and provide counselling facilities to render effective counselling services. The acute shortage of such qualified counsellors in the secondary schools and 
non provision of needed facilities and materials in schools compound the problem of the at-risk students the more deepening their antisocial problems.

In order to intervene positively and curb truancy in secondary school, state governments, should be encouraged to implement the provision of the National Policy on Education (2004) section ii (i) by establishing/restoring counselling services and employing qualified counsellors and building the professional capacity of the few counsellors in schools to provide quality counselling services. In addition, school counsellors should collaborate with both the school authority and the heads of department of different subjects to ensure that teachers employ appropriate methods of teaching and use of multimedia technologies to make their teaching enjoyable and interesting to their students.

It is the responsibility of a counsellor to help individuals to plan, obtain and derive maximum benefit from educational, social, vocational and other kinds of experience which will enable at-risk students to discover and develop themselves, acquire relevant knowledge, skill, attitude, values and interest that would enable them become subject of development.

Parents should work in collaboration with the school and monitor the progress/attendance of their children in school and put more efforts to ensure that their children are adequately provided for and morally groomed. The increasing number of students' enrollment at various levels of education should be matched with the corresponding professionally trained counsellors. There should be enlightenment campaigns by government agencies and nongovernmental organizations for parents and children on the danger inherent in truancy now and in future.

Teachers and Counsellors should endeavor to invite parents of truants for conferences with a view to reducing the incidence of truancy in schools. The current practice of appointing career masters to perform the role of professionally trained guidance counsellors in schools should stop, so that functional guidance and counselling services could be provided for the students.

\section{References:-}

1. Akinade, E.A. (1996). An introduction to guidance and counselling: A basic text for Colleges and Universities. Ibadan: Caltop Publications.

2. Animasahun, R.A. (2008). Academic Success Barrier Battery (ASB2) Stevart Graphics, Ibadan. Caldas, S.J. (1993). Reexamination of input and process factor effects in public school Achievement, Journal of Education Research, 86, 206-214.

3. Carrol, H. (1996). Truancy, absenteeism and delinquency, Scottish, Educational Studies, 14-28

4. Eastwold, P. (1989). Attendance is important: Combating truancy in the secondary school. NASSP Bulletin, 14,23-31.

5. Emore, C. (2005). Causes of students lateness to school in Uvwie L.G.A. of Delta State. Unpublished Post Graduate Diploma in Education Project. Delta State University, Abraka, Nigeria.

6. Ensminger, M.E.\& Slusarcick, A.L. (1992). Paths to high school graduation or dropout: A Longitudinal study of first grade cohort. Sociology of Education, 6,1, 358-377.

7. Fareo, D. O. (2013). Truancy and Academic Performance of Secondary School Students in Southwestern Nigeria: Implication for Counselling. International Journal for Cross-Disciplinary subjects in Education (IJCDSE), Special Issue Volume 3 Issue 2.

8. Faculty of Education, Obafemi Awolowo University, Nigeria.

9. Farrington, D. (1980). Truancy, delinquency, the home, and the school in L. Hersov and I.Berg (eds.), out of school: Modern perspectives in truancy and school refusal (New York, John Wiley \& Sons).

10. Farrington, D.P (2002). Developmental criminology and risk-focused prevention in M. Maguire et al. (eds). The oxford handbook of criminology $\left(3^{\text {rd }}\right.$ ed). Oxford: University Press.

11. Federal Republic of Nigeria (2004). National Policy on Education. Abuja: NERDC Press.

12. Galloway, D. (1982). A study of persistent absentees and their families. British Journal of Education Psychology, 52, 317-330.

13. Herbert, L.F. (2005). Applications Research in Music Education.

14. Jesse L. 2014. Bexar County Commissioners Court. San Antonio, Texas.

15. Kerlinger, F.N. and Lee, H.B. (2000): Foundation of Behavioural Research, $3^{\text {rd }}$ ed. Fort Worth TX: Harcourt Brace. 
16. Maynard, J.U.B (2006). Guidelines for empowering secondary educators, in local parents, in addressing Truancy among early adolescent learners, unpublished PHd Thesis, University of South Africa.

17. Maynard, J.U.B (2014). Truants' perceptions of family factors as causes of school truancy and non-attendance. Journal of Psychology, 5.1: 47-53

18. Nwoje, C.F. (2001). Guidance and counselling: A functional approach Lagos: Josislad Enterprises.

19. Ogunyemi, F.T. (2000): Knowledge and Practice of Montessori principles of Early Childhood Education in Nursery Schools in Ibadan, Oyo State, Ibadan Journal of Educational Studies, 1. 1:48-59.

20. Siziya, S. Muula, A.S.\& Rudatsikira, E. (2007). Prevalence and correlates of truancy Among adolescents in Swaziland; Findings from the global-school-based health survey.

21. Journal of Child and Adolescent Psychiatry and Mental health, Vol.1 (1), 1-15.

22. Ubogu. R.E. (2004). The causes of absenteeism and dropout among secondary school Students in Deltal Central Senatorial District of Delta State Unpublished ph.D. Thesis. Delta State University, Abraka.

23. Uzoeshi, K.C. (2004). Guidance and counseling foundation and practice: Port Harcourt Paragraphies.

24. Wagner, M. Dunkake, I. and Weiss, B. (2004). Truancy in Germany: A Theoretical and Empirical Analysis. Paper presented at a conference European Society or European Societies? Granada, Spain, 18-23 September. Available online at: http//www.uni-koeln.de/wiso-fak/fisoz/forschung/schulver/material/truancy.pdf. accessed 20 March, 2004.

25. Walklate, S. (2003). Understanding criminology - Current theoretical debates. ( $2^{\text {nd }}$ ed.). Maidenhead: Open University Press. 